\title{
Review of Pharmacological Properties and Chemical Constituents of Pastinaca sativa
}

\author{
Hoorieh Mohammadi Kenari ${ }^{1,2}$, Gholamreza Kordafshari ${ }^{3}$, Maryam Moghimi ${ }^{4}$, Fatemeh Eghbalian $^{1,2 *}$, \\ Dariush TaherKhani ${ }^{5}$
}

\author{
${ }^{1}$ Research Institute for Islamic and Complementary Medicine, School of Persian Medicine, Iran University of Medical Sciences, Tehran, \\ Iran \\ ${ }^{2}$ School of Persian Medicine, Iran University of Medical Sciences, Tehran, Iran \\ ${ }^{3}$ School of Persian Medicine, Tehran University of Medical Sciences, Tehran, Iran \\ ${ }^{4}$ Masiha Teb Shomal Knowledge-based Corporation, Sari, Iran \\ ${ }^{5}$ Shahed University of Medical Sciences, Tehran, Iran
}

Received March 28, 2020

Reviewed December 31, 2020

Accepted March 4, 2021
Objectives: Pastinaca sativa (parsnip), is a plant with nutritional and medicinal properties which has been used in all over the world and study about it is rare. In Persian Medicine parsnip is named as zardak and has many uses such as laxative, libido enhancer, kidney stone crusher and diuretic. Because the wide traditional usage of parsnip, in this review the composition and pharmacological properties of this plant are discussed.

Methods: Some data base such as Cochrane, Scopus, PubMed were searched up to 2018 for studies about Pastinaca sativa. In this review study after consider to exclusion criteria, all of the English review and clinical trial were included.

Results: Finally, 46 articles were selected for extraction data about the parsnip. Data extraction based on these studies the most important active ingredients of parsnip include coumarins, furanocoumarins, polyacetylenes, essential oils and flavonoids. Different studies determined that Pastinaca sativa has pharmacological effects in CNS, respiratory, gastrointestinal, liver, skin, cardiovascular and urogenital diseases.

Conclusion: The most important active ingredients in Pastinaca sativa are furanocoumarins, flavonoids and polyacetylenes, and it has many pharmacological properties, including anti-inflammatory, antispasmodic, vasodilator, antifungal, antimicrobial and antidepressant. A main mentioned side effect of parsnip is phototoxicity that was usually reported in direct skin contact. However, family and Some properties and compounds of Pastinaca sativa and Daucus carota are similar but carrots are very popular nowadays. Due to abundant active components and few clinical studies of parsnip, more Studies are recommended to evaluate the effects of it.

Keywords: parsnip, persian medicine, herbal medicine, carrot, pharmacological properties, chemical constituents

\section{INTRODUCTION}

Parsnip (Pastinaca sativa) is an edible root that has long been used in cooking and preparing baby food and livestock [1]. It can also have therapeutic applications depending on the dosage and method of cooking [2]. Parsnip root is high in dietary fiber - about $4.7-4.9 \%$ [1]. Being rich in starch and sugar, the parsnip root is used for human consumption (in soups, cakes, muffins and puddings), animal feed and wine making. Its fresh leaves and buds are also used as vegetables for food and soups. It has various nutritional and therapeutic applications in different countries. For example, in some countries Parsnip is used as an appetizer, digestive and diuretic. The seeds of parsnip contain bitter aromatic substances that increase milk and are also used 
as food spices; it tastes like dill [3].

Pastinaca sativa has different conventional names in Different languages such as Zardak and Wild carrot in Persian, Parsnip in English, Cujtive and Panipainais in French, Jazar in Arabic and Kajer in Indian [4].

From botanical point of view, there is much controversy about distinguishing the parsnip from carrot. Some historians believe the color and taste of the carrots gradually changed over time; the wild carrots were pale white or yellow and the native carrots were pale yellow or purple. Pale white and yellow carrots may come from mutations in the colored carrot gene. In the 18th century Linne for the first time provided a separate scientific name for the two, naming the carrot as Daucus carota and Parsnip as Pastinaca sativa. Galen was the first who explicitly separated Carrot from Parsnip in his writings [5-7].

The Latin name Pastinaca is said to be derived from the Latin word pastino which means "preparing the ground for planting of the vine", but could also originate from the Latin word pastus, meaning "food". The other common names of parsnip are: bird's nest, hart's-eye, heeltrot, hockweed, madnip and queen weed [8].

The effect of different diets on human health is not hidden, and Parsnip is one of the edible roots in some areas. Due to the different nutritional and medicinal uses and wide geographical distribution of parsnip, as well as lack of comprehensive review studies in this field, we decided to summarize the results of research about it in this paper, along with its introduction from the perspective of Persian medicine.

\section{MATERIALS AND METHODS}

\section{Literature search}

The data sources EMBASE, Scopus, PubMed, Web of Science, Google Scholar, CAMEOL, Cinahl, allied and complementary medicine data base, CAMLIN and Iran Medex, clinical trial. Gov, Cochrane, Ovid databases were searched up to 2018 for studies about Pastinaca Sativa as a Mesh term (key word). The strategy of search in PubMed was (Pastinaca sativa [Title/ Abstract]) AND Pastinaca sativa [MeSH Terms].

\section{Inclusion \& exclusion criteria}

All the review and clinical trial, in vivo and in vitro studies with the key Pastinaca Sativa were included. Articles related to the pharmacological properties and active ingredients of parsnip were imported. All unpublished data such as thesis and no abstract available articles were not included. Studies published in language other than English were excluded too.

\section{Study selection}

An initial search of more than 13,000 articles found. After applying initial restrictions (adding keywords related to active ingredients and pharmacological properties), this number decreased to 292.

Two reviewers independently examined the title, abstract and references of each article to eliminate duplications, the articles not including the inclusion criteria and articles whose full text was not available. Disagreements were resolved by discussion. Finally, 46 articles were selected at this stage (Fig. 1).

Two reviewers independently extracted data about the Pastinaca Sativa from the articles, including trial duration, sample size, outcome, results, side effects and Chemical component.

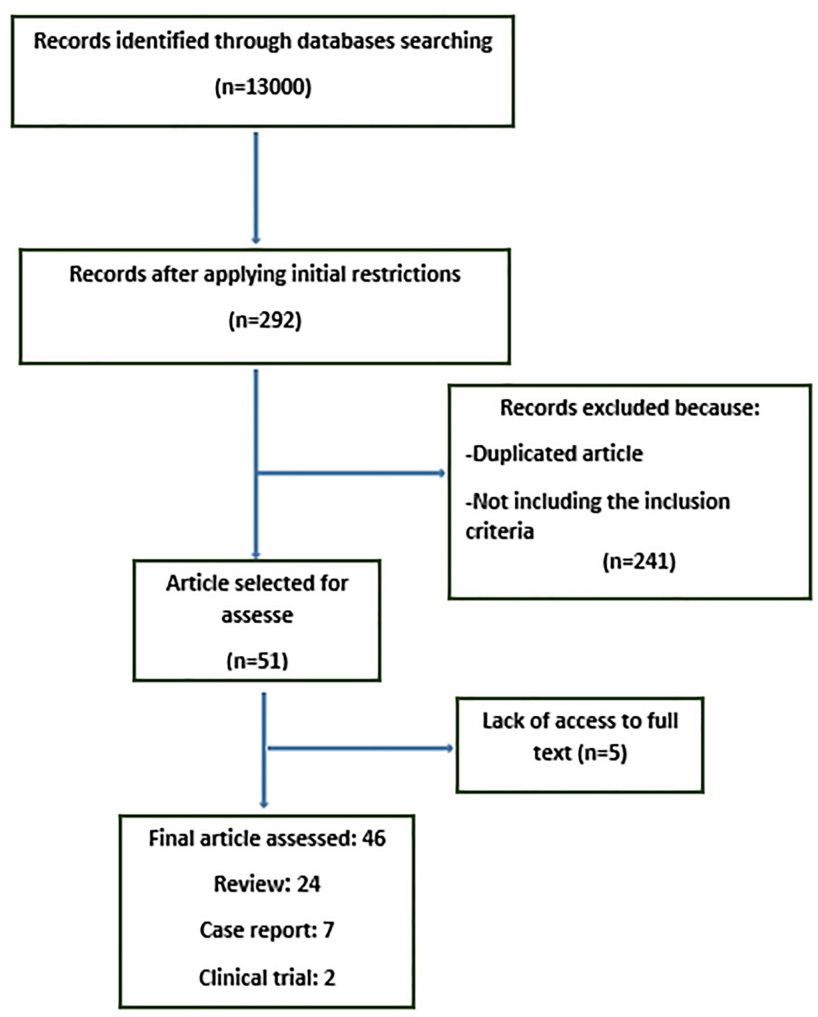

Figure 1. Identification of relevant studies in the review. 


\section{RESULTS}

\section{Morphology}

Parsnip is a biennial plant, 0.3 to $1 \mathrm{~m}$ high, belonging to the Apiaceae family, with fluffy leaves and fusiform roots which is usually red. In the second year, the plant produces a branched stem with alternate leaves leading to flowering umbrellas. The flowers of this plant are small and white in color which form a lumpy structure after maturation. The plant is found all over the world (4), but was originally grown in Asia and Europe, which spread to America and southern Canada from 1,800 onwards. Parsnip has now been colonized in old, abandoned farms, railroads, street sides and unused lands $[8,9]$.

This plant is cultivated in most parts of Iran including Golestan, Mazandaran, Azerbaijan, Hamedan, Fars, Kerman, Khorasan and Tehran [4].

\section{Parsnip from Persian medicine viewpoint}

Persian medicinal plants are valuable sources as nutrients and new treatments for various disorders such as parsnip. Parsnip is called "Jazar" and "Zardak" in Persian medicine resources [10-13]. For example, in Avicenna's Canon, topical and oral use of parsnip is recommended for treatment of headaches, stomatitis, ophthalmitis, dermatitis and fever $[14,15]$. Other properties of Parsnip mentioned in Persian medicine are gastric tonic, laxative, libido enhancer, kidney stone crusher and diuretic [16, 17]. It is also used for treatment of pulmonary diseases such as cough and liver disorders such as obstructive liver diseases and ascites. Topical use of decoction of parsnip is mentioned to be useful for bruising caused by frostbite. Using pickled parsnip orally has been considered as a unique treatment of spleen disorders. From Persian medicine point of view, raw parsnips are hard to digest, so it is better to cook them [18]. So, various food products, including jam, pickles or halva, have been introduced in Persian medicine resources, stating many therapeutic properties [16]. According to Persian medicine, the recommended amount of daily intake of parsnip is up to $600-700 \mathrm{gr}$ for its root, up to $50 \mathrm{gr}$ for its jam and up to $8 \mathrm{gr}$ for its seeds [19].

Persian medicine books have called parsnip seeds as "Doqoo". Its leaves and seeds are highly bloating and promote libido. Oral and topical use of parsnip seeds have been mentioned to facilitate normal delivery [19].

\section{Chemical components}

The most important active ingredients in parsnip include coumarins, furanocoumarins, polyacetylenes, essential oils, terpenes and flavonoids [9, 20-24]. The most important furanocoumarins of parsnip are: xanthotoxin, bergapten, isopimpinellin, angelicin, psoralen, sphondin, and imperatorin [25] All aerial parts of parsnip contain xanthotoxin, bergapten, and imperatorin. Angelicin and sphondin are present in germinal

\section{Table 1. Chemical content of different parts of parsnip}

\begin{tabular}{|c|c|}
\hline $\begin{array}{l}\text { Parts of } \\
\text { parsnip }\end{array}$ & Active ingredients \\
\hline $\begin{array}{l}\text { Aerial } \\
\text { parts }\end{array}$ & $\begin{array}{l}\text { Furanocoumarins (in particular: angelicin, bergaptene, } \\
\text { xanthotoxin, imperatorin, psoralen) } \\
\text { Essential oils (chief components: E- } \beta \text {-ocimene, Z- } \beta \text {-ocimene, } \\
\alpha \text {-terpinolene, E- } \beta \text {-farnesene, } \gamma \text {-palmitolactone, } \\
\text { hexyl butanoate, lavandulyl acetate, sesquiterpene) } \\
\text { Polysaccharides } \\
\text { Organic acids } \\
\text { Hydroxycinnamic acids } \\
\text { Amino acids } \\
\text { Polyphenols }\end{array}$ \\
\hline Root & $\begin{array}{l}\text { Furanocoumarins (in particular: angelicin, bergaptene, } \\
\text { xanthotoxin, imperatorin, psoralen) } \\
\text { Essential oils (chief components: aliphatic ester, in particular } \\
\text { octylbutyrate, Myristicin, } \beta \text {-ocimene, } \beta \text {-farnesene, } \\
\text { octyl butyrate, octyl hexanoate, } \alpha \text {-terpinolene) } \\
\text { Sex hormone (5a-androstenone) } \\
\text { Polysaccharides } \\
\text { Organic acids } \\
\text { Hydroxycinnamic acids } \\
\text { Amino acids } \\
\text { Polyphenols }\end{array}$ \\
\hline Seeds & $\begin{array}{l}\text { Furanocoumarins (bergapten, pimpinellin, methoxsalen, } \\
\text { isopimpinellin, imperatorin, phellopterin, byakangelicol, } \\
\text { heraclenin, isobergapten, byakangelicin, heraclenol, } \\
\text { psoralen, and isobyakangelicin, xanthotoxin) } \\
\text { Essential oils \{myristicin, } \beta \text {-ocimene, } \beta \text {-farnesene, octyl } \\
\text { butyrate, hexanoate, Butyl butyrate, (Z)-b-Ocimene, } \\
\text { Octanal, Hexyl butyrate, Octyl acetate, Decanal, Octanol, } \\
\text { a-Zingiberene, Decanol, b-Sesquiphellandrene, } \\
\text { ar-Curcumene, Decyl butyrate, Benzyl butyrate, } \\
\text { Phenylethyl butyrate, (E)-Nerolidol, Phenylethyl hexanoate, } \\
\text { butyric acid, acetyl ester) } \\
\text { Coumarins (osthol, umbelliferone, 4-hydroxycoumarin) } \\
\text { Hydrocarbons (e.g. methanol, ether, chloroform, ethanol, } \\
\text { chlorophyll) } \\
\text { Resinous substance } \\
\text { Sulphuric acid }\end{array}$ \\
\hline
\end{tabular}


parts of some species $[4,26]$. The active ingredients in the various parts of Parsnip are listed in Table 1 [3, 4, 27-38].

\section{Pharmacological properties}

In 986 A.D, plants containing furanocoumarins were used to treat skin disorders, such as leprosy and vitiligo [8]. Furanocoumarins are also used today to treat some dermatologic diseases. Recent researches about the effect of furanocoumarins on the skin have shown that Heraclenol and oxypeucedanin hydrate have a weak stimulating effect on melanogenesis with no effect on cell proliferation. But these compounds at high concentrations inhibit melanin production and cell proliferation. Byakangelicin is also a dose-dependent inhibitor of melanogenesis [29]. Psoralen also changes in the size and number of melanocytes, including increased tyrosine kinase activity and increased melanosome density [9]. Today, the combination of psoralen or xanthotoxin with UV radiation (PUVA) is used to treat some skin diseases, including vitiligo, mycosis fungoides (a type of skin lymphoma) and psoriasis. But this procedure has some side effects, including erythema, hyperpigmentation, skin epidermal hyperplasia, increased risk of squamous cell carcinoma and malignant melanoma $[8,26]$. The anti-proliferative effect of furanocoumarins, which makes them effective in the treatment of diseases such as psoriasis and mycosis fungoides, is due to selective photo-induced lesions to DNA [26]. Bergapten, oxypeucedanin hydrate, and byakangelicin inhibit compound 48/80-induced histamine levels in the rat peritoneal cavity. Imperatorin of parsnip works against CYP3A4 (Cytochrome P450 3A4) as well as 7-pentoxyresorufin O-depentylase (PROD) [39]. Impatorin in mice shows anticonvulsant activity and enhances the function of anticonvulsants $[40,41]$. Impratorin protects cells against oxidative stress and scopolamine-induced memory impairment and improves the ability to enhance nicotineinduced learning [41]. Isopimpinellin inhibits both 7-pentoxyresorufin O-depentylase (PROD) and 7-ethoxyresorufin Odeethylase (EROD) in hepatocytes [26]. Bergapten also works against CYP2D6 (Cytochrome P450 2D6) [39].

Byakangelicin, psoralen, and isopimpinellin have anti-cholinesterase (ACE inhibitor) effects. Recent studies have shown that byakangelicol has an inhibitory effect on P-glycoprotein in intestinal epithelial cells [29]. P-glycoprotein is responsible for supplying energy for release of drugs such as chemotherapy drugs from cancer cells. In cancer cells, overexpression of this glycoprotein causes multidrug resistance and disrupts treat- ment. Therefore, if this glycoprotein is inhibited, chemotherapy drugs will have a better effect on cancer cells [26]. Heraclenin also has an inhibitory effect on the cytochrome CYP3A4 isoenzyme, much of which is byakangelicol. Furanocoumarin dimers, such as rivulobirin A, have potent inhibitory effects on CYP3A4 [29]. Xanthotoxin, Bergapten, and Angelicin have antifungal activity (against Alternaria, Biopolaris, and Fusarium fungi) [25]. In combination, bergapten and xanthotoxin increase hair growth and are used in the treatment of vitiligo, psoriasis and nesting swollenness [35]. Xanthotoxin also has antioxidant, anti-proliferative and antimicrobial effects [41]. In addition, xanthotoxin has an inhibitory effect on 7-ethoxyresorufin O-deethylase (EROD) in hepatocytes as well as an inhibitory effect on CYP2A6 $[26,42]$ that prolongs the antidepressant and precognitive effects of nicotine and improves the ability to enhance nicotine-induced learning [26]. It also has an anticonvulsant effect in mice and has an inhibitory effect on monoamine oxidase, acetylcholinesterase and butyrylcholinesterase. Its anticonvulsant effect is comparable to that of other anticonvulsants, including valproate, which have many side effects [40,41]. A study found that xanthotoxin acts as a synergist of anticonvulsant drugs including carbamazepine, oxcarbazepine, pregabalin, topiramate, lacosamide and valproate. The anticonvulsant effect of xanthotoxin may be due to changes in voltage-dependent function of sodium and calcium channels in the cell. Xanthotoxin protects cells against oxidative stress and scopolamine-induced memory impairment [41]. Angelicin is anti-inflammatory and anti-fever. This compound exerts its anti-inflammatory effect by inhibiting nitric oxide production in macrophages. Sphondin also acts as an angelicin in this regard. Angelicin also has an inhibitory effect on 7-ethoxyresorufin Odeethylase (EROD) in hepatocytes and has a cytotoxic effect on the human KB cell line. Anglicin and psoralen in combination have antimicrobial effects against Staphylococcus aureus. Angelicin also works against Candida albicans, Cryptococcus neoformans and cladosporium cucumerinum [33].

Some furanocoumarins present in parsnip at concentrations greater than $5 \mu \mathrm{g} / \mathrm{ml}$ have anti-proliferative properties against HeLaS3 cells, which are xanthotoxol, isopimpinellin, bergapten, xanthotoxin, and imperatorin, respectively [33]. Some furanocoumarins are also used in the treatment of depression and multiple sclerosis because these compounds can block potassium channels [26]. The combination of some furanocoumarins has shown different properties, including peripheral vasodilator, coronary artery expander, bronchospasm and abdominal 
smooth muscle spasms eliminator and sedative; so they can be used in angina pectoris, cardioneurorosis with vascular spasm, gastrointestinal cramps, gallbladder disease, kidney and urinary tract disorders [35].

Falcarinol and falcarindiol are polystylenes available in Parsnip. Falcarinol is unstable against heat and $70 \%$ of its effect disappears after 15 minutes of cooking [43]. In humans, falcarinol is absorbed immediately after eating, and because of its lipophilic properties, it can pass through the blood-brain barrier rapidly, enter the brain, and interact with GABA receptors [44]. Falcarinol and falcarindiol have antifungal properties and prevent the growth of fungal spores [45, 46]. Falcarinol was previously known as a food toxin called carotatoxin due to its bitter taste, but studies have now found its anti-nociceptive and anticancer effects [45]. Falcarinol has antibacterial, antiinflammatory and cytotoxic properties. Falcarinol and falcarindiol also have anti-inflammatory and antiplatelet aggregation properties. Falcarinol does this action by altering the catabolism of prostaglandins and inhibiting lipoxygenase. Falcarinol has antibacterial and anti-mycoplasma effects. It also has cytotoxic properties against gastric adenocarcinoma cancer cells in the human. It has recently been shown that falcarinol inhibits the growth of pre-neoplastic cells in the rat colon. Falcarindiol is also anti-mutagenic in addition to being cytotoxic, but this effect is most commonly seen in parsley and celery [45].

Parsnip can inhibit the growth of cancer cells in the breast, colon, lung and prostate because of the high amounts of coumarins. In fact, it has anti-inflammatory properties and prevents angiogenesis of cancer tissue and direct invasion of cancer cells into the body [24]. Some of the coumarins present in parsnip at concentrations greater than $5 \mu \mathrm{g} / \mathrm{ml}$ have anti-proliferative properties against HeLaS3 cells, which are: Osthol, coumarin, umbelliferone, 4-hydroxycoumarin, respectively. Studies have shown that umbelliferone and 4-hydroxycoumarin exert their anti-proliferative effect by inhibiting cellular mitosis. Coumarin and umbelliferone act against malignant prostate cancer, malignant melanoma and renal cell carcinoma [33].

Parsnip contains several essential oils, including: E- $\beta$-ocimene, $\mathrm{Z}$ - $\beta$-ocimene, $\alpha$-terpinolene, E- $\beta$-farnesene $\gamma$-palmitolactone, hexyl butanoate, lavandulyl acetate. These essential oils have an antibacterial effect on the following bacteria: Escherichia coli, Pseudomonas aeruginosa, Salmonella enteritidis, Bacillus cereus, Listeria monocytogenes, Staphylococcus aureus. These compounds also have an antifungal effect against Candida albicans [3].
Studies have shown that the ethanolic extract of Parsnip at the concentration of $300 \mu \mathrm{g} / \mathrm{ml}$ has an apoptotic effect on leukemic cells (C81166 and J45 cell lines). The diuretic effect of parsnip fruits and root is also reported in studies $[46,47]$.

Parsnip root is high in dietary fiber - about $4.7-4.9 \%$. This is because Western countries are interested in using this plant as a source of fiber $[1,38]$.

Some substances in Parsnip protect the plant against insects. myristicin and xanthotoxin are toxic to some insects. Sesquiterpens also have toxic effects on insects and scare them. Fatty acid esters are also lethal to the larvae of some lepidopterans (e.g., butterflies, moths, etc.) [8].

Pharmacological properties of the chemical components of parsnip are listed in Table 2.

\section{Adverse effects}

Furanocoumarins are present in all types of the Apiaceae family including parsnips. These compounds have non-nutritional and phototoxic effects $[8,32,35,36,48]$ which protect the plant against herbivores. UV irradiation increases the toxicity of furanocoumarins. An oral dose of $1 \mathrm{mg} / \mathrm{kg}$ of furanocoumarins may also be dangerous for humans exposing to UV irradiation $[8,26]$. Estimations show that the average daily intake of furanocoumarins by adults is $1.3 \mathrm{mg}$ in the US, $1.45 \mathrm{mg}$ in the Germany and $1.2 \mathrm{mg}$ in the UK, which does not usually reach the phototoxic dose. Studies represent that parsnip consumption containing 45 micrograms of xanthotoxin does not cause any photosensitivity [49]. Phototoxic reaction of furanocoumarins is burning blistering 24 hours after exposure to sunlight (UV-A $320-380 \mathrm{~nm}$ ) [8, 9, 20-22]. This reaction may be mild enough to be unnoticed or severe enough to cause prolonged skin hyperpigmentation after healing $[8,21,34,37]$. The furanocoumarins responsible for this reaction are present in the juice of the plant $[3,8]$. Plant juice is much more irritating at the time of flowering than other times [8]. From molecular point of view, furanocoumarins bind to cellular components, including lipids and proteins, and damage the lysosomes. This damage causes reactive oxygen species, followed by new antigens [26]. In mammals, furanocoumarins are rapidly digested and excreted inducing low toxicity. In a study, Ivie and his colleagues found three types of light-sensitive, mutagenic and photocarcinogenic psoralenes - of furanocoumarins - in cultivated parsnip before and after cooking, with a concentration of about $40 \mathrm{ppm}$. Since cooking (boiling or microwaving) does not alter the nature and 
Table 2. Pharmacological properties of the chemical components of parsnip

\begin{tabular}{|c|c|c|c|}
\hline \multicolumn{3}{|c|}{ Pharmacological properties } & \multirow{2}{*}{$\begin{array}{l}\text { Chemical components } \\
\text { Furanocoumarins }\end{array}$} \\
\hline CNS & Neurologic & Treatment of multiple sclerosis & \\
\hline & & Anticonvulsant & $\begin{array}{l}\text { Xanthotoxin } \\
\text { Imperatorin }\end{array}$ \\
\hline & & Improving cognitive function and memory & $\begin{array}{l}\text { Xanthotoxin } \\
\text { Imperatorin }\end{array}$ \\
\hline & & Sedative & Furanocoumarins \\
\hline & & Interacting with GABA receptors & Falcarinol \\
\hline & Psychiatric & Antidepressant & Furanocoumarins \\
\hline & & MAO inhibitor & Xanthotoxin \\
\hline Respiratory & Eliminating & jasm & Furanocoumarins \\
\hline Gastrointestinal & Eliminating & I smooth muscle spasms & Furanocoumarins \\
\hline Liver and gallbladder & Eliminating & & Furanocoumarins \\
\hline \multirow[t]{7}{*}{ Skin } & Treatment 0 & & Bergapten + Xanthotoxin \\
\hline & Treatment 0 & & $\begin{array}{l}\text { Psoralen } \\
\text { Bergapten }+ \text { Xanthotoxin }\end{array}$ \\
\hline & Treatment 0 & fungoides & Psoralen \\
\hline & Stimulating & nesis & $\begin{array}{l}\text { Oxypeucedanin hydrate (dose-dependent) } \\
\text { Heraclenol (dose-dependent) }\end{array}$ \\
\hline & Inhibiting m & esis & $\begin{array}{l}\text { Oxypeucedanin hydrate (dose-dependent) } \\
\text { Heraclenol (dose-dependent) } \\
\text { Byakangelicin (dose-dependent) }\end{array}$ \\
\hline & Changing in & and number of melanocytes & Psoralen \\
\hline & Increasing h & & Bergapten + Xanthotoxin \\
\hline \multirow[t]{2}{*}{ Blood } & Antiplatelet & & $\begin{array}{l}\text { Falcarinol } \\
\text { Falcarindiol }\end{array}$ \\
\hline & Treatment 0 & & \\
\hline Cardiovascular & $\begin{array}{l}\text { Peripheral v } \\
\text { Coronary ar }\end{array}$ & der & Furanocoumarins \\
\hline \multirow[t]{3}{*}{ Urogenital } & Eliminating & & Furanocoumarins \\
\hline & Impact on s & & Sex hormone (5a-androstenone) \\
\hline & Diuretic & & - \\
\hline \multirow[t]{2}{*}{ Microorganisms } & Antibacteria & & $\begin{array}{l}\text { Xanthotoxin } \\
\text { Angelicin + Psoralen } \\
\text { Falcarinol } \\
\text { Essential oils }\end{array}$ \\
\hline & Antifungal & & $\begin{array}{l}\text { Bergapten } \\
\text { Xanthotoxin } \\
\text { Angelicin } \\
\text { Falcarinol } \\
\text { Falcarindiol } \\
\text { Essential oils }\end{array}$ \\
\hline
\end{tabular}

concentration of these psoralens, people who use the parsnips orally are exposed to significant amounts of these substances. However, studies show that allergenic furanocoumarins in cul- tivated parsnip are less than wild parsnip [8].

Falcarinol is one of the allergy-inducing substances in the apiaceae family but falcarindiol is not an allergen [43-46]. 
Hoorieh Mohammadi Kenari, et al.

Table 2. Continued

\begin{tabular}{|c|c|c|}
\hline \multicolumn{2}{|r|}{ Pharmacological properties } & \multirow[t]{2}{*}{ Chemical components } \\
\hline Cancers & Improving the effect of chemotherapy drugs on cancer cells & \\
\hline & Cytotoxic effect on human KB cell line & Angelicin \\
\hline & Anti-proliferative effect on HeLaS3 cells & $\begin{array}{l}\text { Bergapten } \\
\text { Isopimpinellin } \\
\text { Xanthotoxin } \\
\text { Xanthotoxol } \\
\text { Imperatorin } \\
\text { Coumarins }\end{array}$ \\
\hline & Cytotoxic effect on human gastric adenocarcinoma & Falcarinol \\
\hline & Inhibiting the growth of pre-neoplastic cells in the rat colon & Falcarinol \\
\hline & Anti-mutagenic and cytotoxic & Falcarindiol \\
\hline & Inhibiting the growth of cancer cells in the breast, colon, lung and prostate & Coumarins \\
\hline & $\begin{array}{l}\text { Preventing angiogenesis of cancer tissue and direct invasion of cancer } \\
\text { cells into the body }\end{array}$ & Coumarins \\
\hline & Apoptotic effect on Leukemic cell lines & 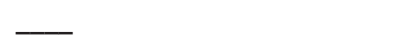 \\
\hline \multirow[t]{3}{*}{ Others } & Antioxidant & Xanthotoxin \\
\hline & Anti-fever & Angelicin \\
\hline & Anti-inflammatory & $\begin{array}{l}\text { Angelicin } \\
\text { Sphondin } \\
\text { Falcarinol } \\
\text { Falcarindiol }\end{array}$ \\
\hline
\end{tabular}

Some studies have shown that mice exposed to coumarincontaining plant extracts (e.g., parsnip) or 4-hydroxycoumarin extracted from the plant develop hypothrombinemia and internal or external bleeding that is similar to the symptoms of warfarin toxicity. Coumarin anti-coagulants are contraindicated in pregnant women because they cross the placenta and cause fetal bleeding in the uterus, increasing the probability of spontaneous abortion and fetal deformities [33].

\section{DISCUSSION}

Nowadays, the use of medicinal plants has become widespread worldwide. Recent researches demonstrated that many plants and/or their constituents were used as a prevention and/ or treatment for many diseases [50-52].

Parsnip, as an edible root, has long been used in food and medicine in most parts of the world due to its abundant active components including furanocoumarins, polysaccharides and organic acids, which have many pharmacological properties including anti-inflammatory, antispasmodic, vasodilator, antifungal, antimicrobial and antidepressant. Ancient Persian scholars have also described it as a nutritious and fortifying food, so it has been used in the past for children and people with physical disabilities. The most common use of Parsnip was its jam, which is still used in Iran. However, in Persian medicine, raw parsnip consumption is not recommended because it is considered to be bloating and hard to digest [53]. Additionally, Persian medicine believed that parsnip is emmenagogue, so it was prohibited for pregnant women. Of course, this property has sometimes been used to treat amenorrhea or oligomenorrhea, which is today confirmed by the literature.

Another side effect of parsnip mentioned in the articles is phototoxicity. It was usually reported as case reports in which skin contact with parsnip and then exposure to UV irradiation caused allergic dermatitis. It has been reported in the literature that this reaction is due to the presence of furanocoumarins in parsnip commonly found in the juice. Since in mammalians furanocoumarins are rapidly digested and excreted from the body, its oral intake, except in high doses, is less likely to cause skin reactions. Therefore, most of the reported cases of skin allergies have been caused by topical contact resulted in contact dermatitis.

Due to the increasing use of medicinal herbs in various medical fields, there are many researches in this area confirm- 
ing the mentioned properties and applications of the plants in complementary medicine resources. Accordingly, further studies should be carried out on some of the other properties of parsnip, such as effect on spleen diseases, that have been mentioned in Persian medicine resources.

As mentioned, the scientific name of carrots and parsnip is different although some believe that pale white and yellow carrots may have been derived from mutations in the color carrot gene $[5,6]$.

\section{CONCLUSION}

Nowadays, carrots are more popular in the food and pharmaceutical industries and their consumption is higher, however, given the similarity of carrot and parsnip compounds and therapeutic properties $[54,55]$, further studies are needed to better understanding the health benefits of parsnip.

\section{ACKNOWLEDGMENT}

This research did not receive any specific grant from funding agencies in the public, commercial, or not-for-profit sectors.

\section{CONFLICT OF INTEREST}

The authors have no conflict of interest and all authors listed have contributed sufficiently to the project. This research has no financial support.

\section{AUTHORS' CONTRIBUTION}

Fatemeh Eghbalian is study designer and has approve the final manuscript. Other authors searching the data and writing the primary format of the article. This research has no financial support.

\section{ORCID}

Hoorieh Mohammadi Kenari, https://orcid.org/0000-0003-0658-5284 Gholamreza Kordafshari, https://orcid.org/0000-0001-9052-9626 Maryam Moghimi, https://orcid.org/0000-0003-1656-0873 Fatemeh Eghbalian, https://orcid.org/0000-0002-4668-3025 Dariush TaherKhani, https://orcid.org/0000-0002-3650-4177

\section{REFERENCES}

1. Castro A, Bergenståhl B, Tornberg E. Parsnip (Pastinaca sativa L.): dietary fibre composition and physicochemical characterization of its homogenized suspensions. Food Res Int. 2012;48(2):598-608.

2. Stannard J. Medicinal plants and folk remedies in Pliny, Historia naturalis. Hist Philos Life Sci. 1982;4(1):3-23.

3. Matejić JS, Džamić AM, Mihajilov-Krstev T, Ranđelović VN, Krivošej ZĐ, Marin PD. Antimicrobial potential of essential oil from Pastinaca sativa L. Biol Nyssana. 2014;5(1):31-5.

4. Emami A, Fasihi S, Mehregan I. Reference book on medicinal plants. Tehran: Islamic and Complementary Medicine at Iran University of Medical Sciences; 2010. 1002 p.

5. Stolarczyk J, Janick J. Carrot: history and iconography. Chron Horticult. 2011;51(2):13-8.

6. Grant M. Galen on food and diet. London: Routledge; 2000. p. 151.

7. Bahrami R, Ghobadi A, Behnoud N, Akhtari E. Medicinal properties of Daucus carota in traditional Persian medicine and modern phytotherapy. J Biochem Tech. 2018;9(2):107-14.

8. Averill KM, DiTommaso A. Wild parsnip (Pastinaca sativa): a troublesome species of increasing concern. Weed Technol. 2007;21(1):279-87.

9. Walling AL, Walling HW. Phytophotodermatitis induced by wild parsnip. Dermatol Online J. 2018;24(2):19.

10. Eghbalian F, Esmaili N, Karimi M, Mohajerani F, Rahimi R, Atyabi A, et al. Comparison of the efficacy and tolerability of an oral dosage form made from Fumaria vaillantii versus cetirizinein management of chronic urticaria: a single-blind, randomized, clinical trial. Biomed Res Ther. 2018;5(6):2389-401.

11. Avicenna H. [Canon of medicine]. Beirut: Ehyaol Toras al-Arabi Press; 2010. p. 263-4. Arabic.

12. Tonekaboni HM. [A gift for the faithful]. Tehran: Research Center of Traditional Medicine. Shahid Beheshti University of Medical Sciences. Shahr Publication; 2007. 265 p. Persian.

13. Aghili Alavi Khorasani MH. [Reservoir of medicine]. Tehran: Intisharat va Amoozesh Enghelab Islami Press; 1992. 303 p. Persian.

14. Akramo Sadat A, Fatemeh N, Fatemeh E, Laila S, Hoorie Mohammadi K, Mohammad Hossein A. Persian medicine nonpharmacological therapies for headache: phlebotomy and wet cupping. J Tradit Chin Med. 2018;38(3):457-64.

15. Mahdizadeh S, Khaleghi Ghadiri M, Gorji A. Avicenna’s Canon of Medicine: a review of analgesics and anti-inflammatory substances. Avicenna J Phytomed. 2015;5(3):182-202.

16. Aghili Khorasani Shirazi MH. [Great pharmacopoeia]. Tehran: Mahmoudi Press; 1970. 522 p. Persian. 
17. Shoja MM, Tubbs RS, Bosmia AN, Fakhree MA, Jouyban A, Balch MW, et al. Herbal diuretics in medieval Persian and Arabic medicine. J Altern Complement Med. 2015;21(6):309-20.

18. Razes. [Liber continent]. Beiruot: Ehyaol Toras al-Arabi Press; 2001. 21 p. Arabic.

19. Mirheydar H. [Herbal knowledge]. 7th ed. Tehran: Islamic Culture Publication; 2007. p. 305. Persian.

20. Harper N, Orpin S, Mehta A. The root cause of a blistering eruption. Arch Dis Child. 2015;100(1):72.

21. Seavy L, Rizzolo D. Blistering rash and erythema on the chest and arms. JAAPA. 2013;26(2):12.

22. Heywood VH. The socio-economic importance of the Apiales. J Fac Pharm Istanbul. 2014;44(2):113-30.

23. Jensen T, Hansen KG. Active spectral range for phytogenic photodermatosis produced by Pastinaca sativa: (dermatitis bullosa striata pratensis, Oppenheim). Arch Derm Syphilol. 1939;40(4): 566-77.

24. Amri E. The role of selected plant families with dietary ethnomedicinal species used as anticancer. J Med Plants Stud. 2014; 2(1):28-39.

25. Al-Barwani FM, Eltayeb EA. Xanthotoxin and other furanocoumarins as phytoalexins in Pastinaca sativa L. roots. SQU J Sci. 2004;9:7-17.

26. Conforti F, Marrelli M, Menichini F, Bonesi M, Statti G, Provenzano E, et al. Natural and synthetic furanocoumarins as treatment for vitiligo and psoriasis. Curr Drug Ther. 2009;4(1):38-58.

27. Chizzola R. Essential oil composition of wild growing Apiaceae from Europe and the Mediterranean. Nat Prod Commun. 2010;5(9):1477-92.

28. Kurkcuoglu M, Baser KHC, Vural M. Composition of the essential oil of Pastinaca sativa L. subsp. urens (Req. ex Godron) Celak. Chem Nat Compd. 2006;42(1):114-5.

29. Kviesis J, Kḷimenkovs I, Arbidans L, Podjava A, Kḷaviņš M, Liepiņš E. Evaluation of furanocoumarins from seeds of the wild parsnip (Pastinaca sativa L. s.l.). J Chromatogr B Analyt Technol Biomed Life Sci. 2019;1105:54-66.

30. Jamshidi AH, Eghbalian F, Mahroozade S, Kenari HM, Ghobadi A, Yousefsani BS. Recommended natural products in Alzheimer's disease based on traditional Persian medicine. J Med Plants. 2020;19(75):17-29.

31. Janeczko A, Skoczowski A. Mammalian sex hormones in plants. Folia Histochem Cytobiol. 2005;43(2):71-9.

32. Soine TO, Abu-Shady H, Digangi FE. A note on the isolation of bergapten and imperatorin from the fruits of Pastinaca sativa $\mathrm{L}$. J Am Pharm Assoc Am Pharm Assoc. 1956;45(6):426-7.

33. Madari H, Jacobs RS. An analysis of cytotoxic botanical formulations used in the traditional medicine of ancient Persia as abortifacients. J Nat Prod. 2004;67(8):1204-10.
34. Fahmy IR, Kadir EA, Saber AH. A pharmacognostical study of the fruit of Pastinaca sativa L. cultivated in Egypt. J Pharm Pharmacol. 1956;8(9):653-60.

35. Nemych VA, Donakanian NS, Novosel OM, Horyacha LM, editor. Phytochemical analysis of the leaves and root crops of Pastinaca sativa. Proceedings of Topical Issues of New Drugs Development: Abstracts of XXV International Scientific and Practical Conference of Young Scientists and Student; 2018 Apr 18-20; Kharkiv, Ukrainian. Kharkiv (Ukrainian): NUPh; c2018. p. 58-9.

36. Mongeau R, Brassard R, Cerkauskas R, Chiba M, Lok E, Nera EA, et al. Effect of addition of dried healthy or diseased parsnip root tissue to a modified AIN-76A diet on cell proliferation and histopathology in the liver, oesophagus and forestomach of male Swiss Webster mice. Food Chem Toxicol. 1994;32(3):265-71.

37. Picardo M, Cristaudo A, de Luca C, Santucci B. Contact dermatitis to Pastinaca sativa. Contact Dermatitis. 1986;15(2):98-9.

38. Terreaux C, Polasek J, Hostettmann K. Plant constituents with hormonal effects. Curr Org Chem. 2003;7(12):1151-61.

39. Briguglio M, Hrelia S, Malaguti M, Serpe L, Canaparo R, Dell'Osso B, et al. Food bioactive compounds and their interference in drug pharmacokinetic/pharmacodynamic profiles. Pharmaceutics. 2018;10(4):277.

40. Skalicka-Woźniak K, Zagaja M, Głowniak K, Łuszczki JJ. Purification and anticonvulsant activity of xanthotoxin (8-methoxypsoralen). Cent Eur J Biol. 2014;9(4):431-6.

41. Skalicka-Wozniak K, Budzynska B, Biala G, BoguszewskaCzubara A. Scopolamine-induced memory impairment is alleviated by xanthotoxin: role of acetylcholinesterase and oxidative stress processes. ACS Chem Neurosci. 2018;9(5):1184-94.

42. Fang ZZ, Zhang YY, Wang XL, Cao YF, Huo H, Yang L. Bioactivation of herbal constituents: simple alerts in the complex system. Expert Opin Drug Metab Toxicol. 2011;7(8):989-1007.

43. Paulsen E, Petersen TH, Fretté XC, Andersen KE, Christensen LP. Systemic allergic dermatitis caused by Apiaceae root vegetables. Contact Dermatitis. 2014;70(2):98-103.

44. Czyzewska MM, Chrobok L, Kania A, Jatczak M, Pollastro F, Appendino G, et al. Dietary acetylenic oxylipin falcarinol differentially modulates GABAA receptors. J Nat Prod. 2014;77(12): 2671-7.

45. Christensen LP, Brandt K. Bioactive polyacetylenes in food plants of the Apiaceae family: occurrence, bioactivity and analysis. J Pharm Biomed Anal. 2006;41(3):683-93.

46. Bogucka-Kocka A, Smolarz HD, Kocki J. Apoptotic activities of ethanol extracts from some Apiaceae on human leukaemia cell lines. Fitoterapia. 2008;79(7-8):487-97.

47. Sobhani Z, Nami SR, Emami SA, Sahebkar A, Javadi B. Medicinal plants targeting cardiovascular diseases in view of Avicenna. 
Curr Pharm Des. 2017;23(17):2428-43.

48. Yarnell E, Touwaide A. Accuracy of Dioscorides', De materia medica (First Century C.E.), regarding diuretic activity of plants. J Altern Complement Med. 2019;25(1):107-20.

49. Gorgus E, Lohr C, Raquet N, Guth S, Schrenk D. Limettin and furocoumarins in beverages containing citrus juices or extracts. Food Chem Toxicol. 2010;48(1):93-8.

50. Yousefsani BS, Mehri S, Pourahmad J, Hosseinzadeh H. Crocin prevents sub-cellular organelle damage, proteolysis and apoptosis in rat hepatocytes: a justification for its Hepatoprotection. Iran J Pharm Res. 2018;17(2):553-62.

51. Baradaran Rahimi V, Askari VR, Hosseini M, Yousefsani BS, Sadeghnia HR. Anticonvulsant activity of Viola tricolor against seizures induced by pentylenetetrazol and maximal electroshock in mice. Iran J Med Sci. 2019;44(3):220-6.

52. Yousefsani BS, Pourahmad J, Hosseinzadeh H. The mechanism of protective effect of crocin against liver mitochondrial toxicity caused by arsenic III. Toxicol Mech Methods. 2018;28(2):10514.

53. Larijani B, Esfahani MM, Moghimi M, Shams Ardakani MR, Keshavarz M, Kordafshari G, et al. Prevention and treatment of flatulence from a traditional Persian medicine perspective. Iran Red Crescent Med J. 2016;18(4):e23664.

54. Dr. Duke's Phytochemical and Ethnobotanical Databases Chemicals found in Daucus carota [Internet]. Washington D.C.: U.S. Department of Agriculture, Agricultural Research Service; 19922016 [cited 2018 Aug 14]. Available from: https://phytochem. nal.usda.gov/phytochem/plants/show/602? et.

55. Dr. Duke's Phytochemical and Ethnobotanical Databases Chemicals found in Pastinaca sativa [Internet]. Washington D.C.: U.S. Department of Agriculture, Agricultural Research Service; 19922016 [cited 2018 Aug 14]. Available from: https://phytochem. nal.usda.gov/phytochem/plants/show/1440?et. 